\title{
The Effect of Landscape Features implemented in Egyptian Parks on satisfying the Human needs and well-being
}

\author{
MARIANNE NABIL GUIRGUIS, RANIA RUSHDY MOUSSA, KHALED M. DEWIDAR, \\ \& NAGLAA MOHAMED YOSSIF \\ Architectural Engineering Department \\ The British University in Egypt (BUE) \\ El-Sherouk City, Cairo 11837 \\ EGYPT
}

\begin{abstract}
Recently, parks have been recognized as one of the main contributors in the strategic objectives of urban projects, since they provide job opportunities, place attractiveness, increase the real estate market and property values, tourist development, increase the since of social belonging between the residents, improving the public health and the quality of the residents' life. The presented research is aiming to investigate the effect of Landscape features on the quality of life (QOL) inside Egyptian parks. This study has been inspired by early theorists like "Maslow" and other theorists who have followed Maslow's footsteps. They analysed and measured the concept of quality of life (QOL)into two well-known terms "human needs" and "well-being". The study explores the impact of landscape features towards "human needs and well-being". Lately, Egypt is suffering from inflation and economic crisis which affect the Egyptians life style. Most of the Egyptian society is living a stressful life; this study will examine whether the Egyptian parks help Egyptians as an escape way where all the negative vibes are going to meet with nature resulting in a positive outcome. This research used qualitative investigation method to measure the impact of implementing landscape features in Egyptian parks on enhancing the quality of the Egyptian life by measuring the (QOL) with regards to "human needs and wellbeing". The presented research investigated the impact of landscape elements implemented in Al-Azhar Park and Family Park on "human needs and well-being". That shall pave the way to investors, policymakers, architecture and civil practitioners to realize the potentials of designing and constructing parks in Egyptian urban environment, as an efficient tool to improve the quality of Egyptian life.
\end{abstract}

Keywords: -Landscape features; Quality of life (QOL); Al-Azhar Park; Family Parks; Well-being Human needs;

Received: May 5, 2021. Revised: November 11, 2021. Accepted: December 12, 2021. Published: January 9, 2022.

\section{Introduction}

During the thirties of the past century, researchers and theorists started to study and eager to classify, analyse, probe the concept of (QOL)[1].(QOL) not only became a debatable subject among researches, but also, it gained the interest of theorists, economists and politicians. For example, in fifties, Osborn and Ordway well-known economists, debated over the economic context of the term of (QOL)[1].A number of years later, theorists began to publish books that try to study the concept into depth. For example, Galbraith wrote a couple of books published named, "The Affluent Society" and "The Industrial State". Through his writings, Galbraith ensured the industrial age that influence in a positive way the economy whilst ruining human's (QOL). The concept is distinctly demonstrated by his writings "What counts is not the quantity of our goods but the quality of life" [1]. Years back, in the seventies, the quality of life expression turned out to be an area of study, precisely an academic field. Plentiful of studies, academic articles and journals whichever study (QOL) and well-being got considerable [2]. Ever after 1985, the average of written articles got regularly growing to the point it counted 20900 articles [2]. Furthermore, (QOL) assemblies began to emerge like "The International Society for Quality of Life Studies" assembly whichever encouraged researchers and theorists to dispute and analyse that concept [2]. For more than three decades until current, the (QOL) concept got fostered and raised by a lot of governments, organizations, and agencies internationally [2]. The 
UNESCO, the OECD, and the WHO execute fundamental studies regarding (QOL) with a view to observe the differences occurred within states, provinces, as well as cities [2]. Lastly, scientists reached the conclusion that quality of life is a comprehensive concept which adopt a lot of different fields such as education, health, enjoyment, personal freedom, and [1].

The concept of (QOL)expanded throughout the past years. Theorists fostered and developed the concept over the year's long time ago, to include several other fields. The concept attracts individual researchers and grew to be the fundamental study of governments and organizations as well. (QOL) would still be a very interesting field of study for the forthcoming year.

The aim of this research is to investigate the effect of landscape elements on the quality of life and its effect on satisfying the human needs and well-being.

\subsection{Measurements and Parameters of (QOL)}

The (QOL) shall get demonstrated and deliberated in singular definitions; a path wherever any subject or person make their own terms and expressions whichever might considered further convenient measure [3].

Several fields of research began studying (QOL) ever after the thirties [4]. Researchers attempted to distinguish the components and parameters of (QOL) and contrasted different geographical regions like cities, states and nations by means of (QOL)indicating that they adopted $[5,6,7,8,9]$.Moreover, researchers and international organizations such as [16].have been developing measures on their own for the (QOL), this is the reason we now got a lot of measurements and parameters whichever determine the (QOL), that gives the conclusions of several outcomes of studies on the (QOL) as a result of the variance in the selected sets of variable aspects and measurements [10]. In table [1] it's almost impossible to get the same aspects set of (QOL) in the literatures; although, (QOL) have similar aspects like Environmental, Social and finally Economic. (QOL) aspects are only in exceptional times measured by the same unit. These aspects names may be misguiding in a lot of cases. Ulengin (2001) stated that: "Some of those aspects are measured with irrelevant indicators such as Wish (1986) criticized, Liu (1976) he had measured his social aspect by fifty-four indicators which are common between political and economic aspects and those indicators are common with the social component, which leads to double counting, and to bias" $[4,5,10]$.

A lot of studies sustain to give more weight for several schemes and aspects or even variables further than another aspect or variable. In a lot of different studies, the weighting process (whether it is similar weights or various) is totally up to the researcher decision.

Table 1. Parameters affecting the quality of life (QOL) Source: adapted from Moussa, 2013

\section{Sourc Aspects}

[5] (1) Environmental; (2) Economic; (3) Social; (4) Political and (5) educational \&health

[6] (1)Health care \& environment, (2)Education, (3)Economics, (4)Housing, (5)Arts, (6)Crime, (7)Climate, (8)Transportation, and (9)Recreation

[7,8] (1) heating degree days, (2) coast, (3) total suspended particulates, (4) cooling degree days, (5) violent crime, (6) NPDES effluent discharges, (7) wind speed, (8) teacher pupil ratio, (9) landfill waste, (10) sunshine, (11) visibility, (12) superfund sites, (13) Precipitation, (14) central city, (15) humidity, and (16) treatment, storage and disposal sites

[9] (1)Living space, (2)Education, (3)Clean air, (4)Housing standard, (5)Public health, (6)Food cost, (7) Traffic flow, (8)Public safety, (9)Peace and quiet, and (10) Communication

[10] (1)Economic environment quality, (2)Social environment quality, (3)Transportation \& communication quality, and (4)Physical environment quality

Flynn (1)Economic indicators, (2)Social indicators, and et, al. (3)Environmentally indicators

(2002)

[11] (1)Economic, (2)Ecological, (3)Social

[12] (1)Public health benefits, (2) Economic benefits, (3) Environmental Benefits, (4) Social Benefits

[13] (1)Air pollution in the urban spaces, (2)Aesthetics and the environment, (3)Open spaces, the environment quality in residential neighbourhoods and the built density, (4)Public participating and the urban environment, (5)Environmental evaluation system for building and spaces, (6)Noises in the urban spaces, and (7)Transportation factor

[14] (1)Social benefits, (2)Aesthetic and architecture benefits, (3)Climatic and physical benefits, (4) Ecological benefits, (5)Economic benefits

[15] (1)Social, (2) Economic, (3) Ecological Values

[16] (1)Environmental, (2) Economic, (3) Social

[17] (1)Environmental, (2) Social, (3)Economic 
Furthermore, a quite large figure of tests was established for measuring the (QOL). The(QOL) differs majorly regarding concept, construction and content; subsequently, a direct comparison is not always convenient with one another [18]. Each of the indicators of objectives and subjectives are considered as measures for the (QOL). Objective measures characterized by not being subjected to the error of observation; however, they are not sensitive to all sensations about the subject[19]. All of those measures have and been demonstrated concerning the dependability of several measures, for instance: income, housing density and crime rates[20]. Wellbeing parameters are a subjective parameters and

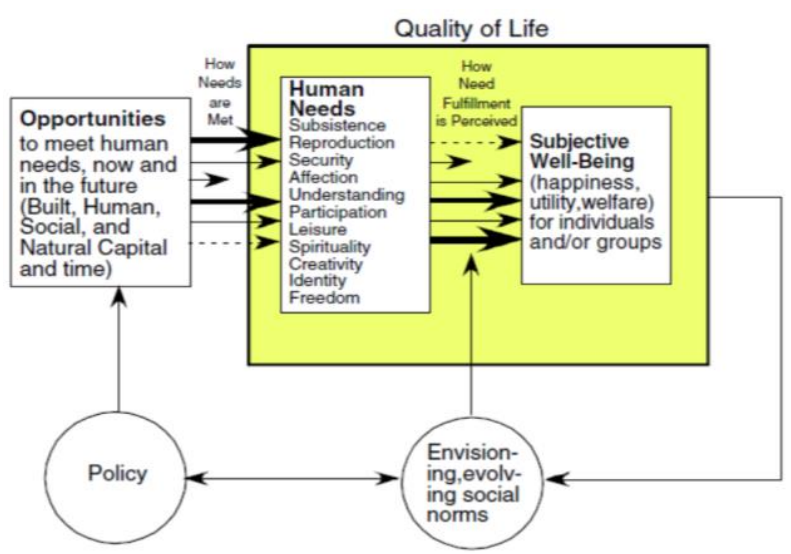

Fig. 1.Quality of Life (QOL) as the interaction of human needs and the subjective perception of their fulfilment, as mediated by the opportunities available to meet the needs. Source: Costanza et al. (2007)

they include utility, job satisfaction, welfare, happiness for persons or clusters and perceptions of health and morale encompass subjects getting told for making decisions regarding their lives; that is the power of subjective measures."People's perceptions however, uninformed they may be, are real and people act on the basis of them" [19].

\subsection{Framework of (QOL)}

In this research, the framework of the(QOL) got fostered as a result of it being utmost convenient framework regarding such research and it was the latest framework when this research started. It describes the meaning of the (QOL) and the needs of this generation and this time period [21]. Costanza, et al. (2007) specified (QOL) to estimating human needs by subjective well-being or happiness. (QOL) has presented as a multi-scale, multi-dimensional concept that accommodates interacting elements both objective and subjective. Furthermore, they make a relation between (QOL) and the chances whichever given for reaching human needs in the form of natural capital, built, social and human as shown in figure [1]. The adapted framework of [21] specified (QOL) with a definition of 'objective human needs in relation to

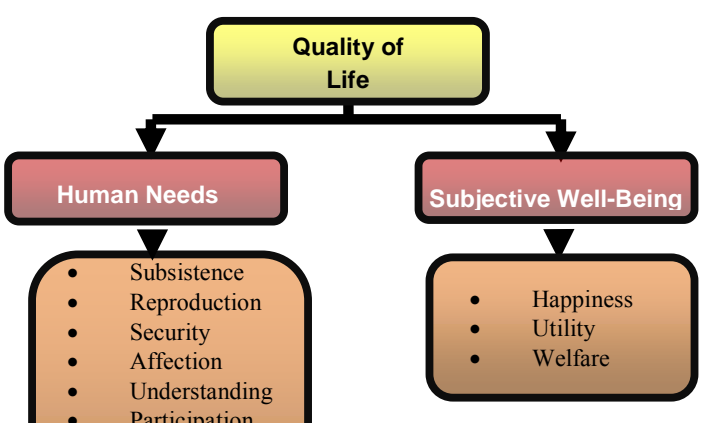

Fig. 2.The Adopted model for studying Quality of Life (QOL)

personal or group perceptions of subjective wellbeing'[21]. However, measurement in terms of 'human needs' and ' well-being' can be done as shown in figure [2].

\subsubsection{Human Needs:}

Abraham Maslow is a pioneer theorist that developed the 'Hierarchy of Needs' theory,considered to be an original example for the humanist philosophy followed by many others theorists[22]. Maslow's theory of hierarchy of human needs specified five different levels of needs, whichever involve 'physiological', 'safety', 'belonging', 'esteem' and 'self-actualization' needs. All of the five levels require to be fulfilled so as to achieve a healthy and full-functioning human being. Recently, he included two more levels into that hierarchy, named 'cognitive' and 'aesthetic' needs, whichever got allocated prior to 'self-actualization' within this frame of reference.

if one or more of Maslow's needs is not satisfied, the individual will tend to be arrested at that developmental stage, unable to progress to further stages until that need is met" [22].

Kök, (2007) added "human needs are a powerful source of explanation of human behaviour and social interaction ... social systems must be responsive to individual needs, or be subject to instability and forced change" [23].

Several researchers carried on with Maslow's path presenting further categorizations in order to add new coming out needs. Examples for those researchers include Maslow himself when he developed him model in 1943 [21,24,25,26,27].

All of them couldn't agree more on a suitable model that has to go through development in order to inscribe basic needs, safety and security, love and 
belonging, self-esteem and self-actualization. They fundamentally had differences in specifying all elements which every category includes. Table [2] below shows how the aspects inscribed for every category differ for each model. It is based on other studies within small modifications in order to help the present research purposes[23]. Maslow added the fundamental categories of human needs during time when different researchers and philosophers modifies his model to suit the new human needs, and they created different parts from those model aspects so as to achieve more specified parts. For example, Max-Neef split up the Aesthetic needs of Maslow to Affection and Leisure and Costanza originated a category of Max-Neef's. In addition, Max-Neef substituted the naming of 'Cognitive needs' of Maslow to 'Understanding'[21, 24, 28].

Table 2. Human Needs, as presented by various theorists (Moussa, 2013)

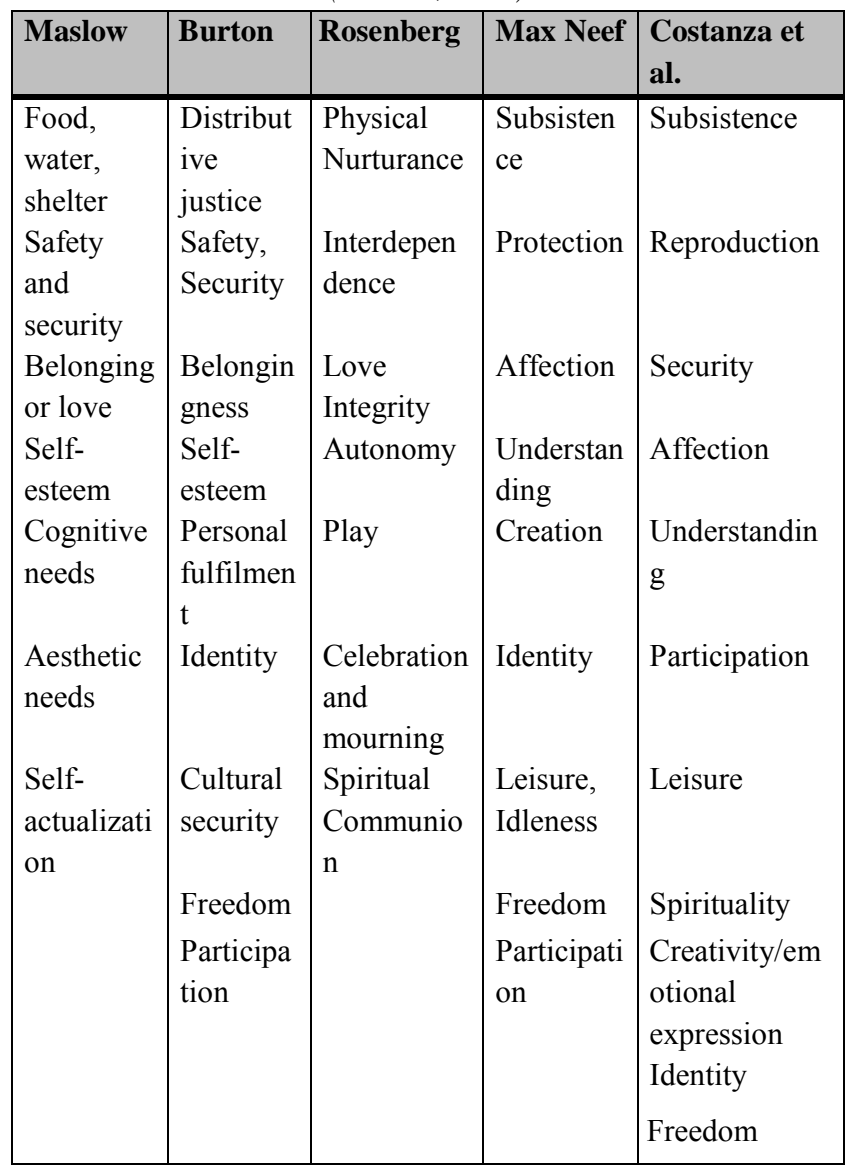

Established upon the above table [2], we came to know that those researchers and philosophers adjusted Maslow's model of human needs so as to achieve accommodation to the time period. That became the fundamental reason of choosing Costanza's model. The framework of human needs of Costanza, et al. (2007) was based on Max-Neef's
(1992) Matrix of Human Needs and Abraham Maslow's Hierarchy of Human Needs[21,28].

Max-Neef's (1992) divided the human needs into nine aspects as follows:

- Subsistence: wholeness, order, consumption, wasting, motion, activity, heat, accessibility, flexibility, growing and willingtobealive.

- Protection: keeping physical livelihood, keeping mentally and emotionally well-being.

- Affection: enjoyment, belief, devotion, admiration, beauty, sense. Engagement: receive and give.

- Understanding: awareness, knowledge, learning and reflexing.

- Creation: transfigure, change symbols and reshaping.

- Idleness: cleansing and relief.

- Identity: physical distinction and looks, mentality, previous experiences and desire.

- Freedom: worth, choosing and preference.

- Transcendence: declaration of living and avoidno meaningful absurd.

Costanza et al. (2007) framework of human needs[21, 24, 28], whichever was adjusted from Max-Neef, contains eleven aspects as presented and designated in table [3].

Table 3. Costanza et al., (2007) list of human needs and their description

Source: Costanza. et al. (2007)

\begin{tabular}{|c|c|}
\hline Human needs & Description (direct satisfiers) \\
\hline Subsistence & $\begin{array}{l}\text { Food, shelter, vital ecological } \\
\text { services(clean air and water, etc.) } \\
\text { healthcare, rest }\end{array}$ \\
\hline Reproduction & $\begin{array}{l}\text { - Nurturing of children, pregnant } \\
\text { women } \\
\text { - Transmission of the culture } \\
\text { - Homemaking }\end{array}$ \\
\hline Security & $\begin{array}{l}\text { - Enforced predictable rules of } \\
\text { conduct } \\
\text { - Safety from violence at home and } \\
\text { in public } \\
\text { - Security of subsistence into the } \\
\text { future } \\
\text { - Maintain safe distance from } \\
\text { crossing critical } \\
\text { - ecological thresholds } \\
\text { - Stewardship of nature to ensure } \\
\text { subsistence into the future } \\
\text { - Care for the sick and elderly }\end{array}$ \\
\hline Affection & $\begin{array}{l}\text { "Being able to have attachments to } \\
\text { things and persons outside } \\
\text { ourselves; to love those who love } \\
\text { and care for us, to grieve at their } \\
\text { absence." (Nussbaum as referenced } \\
\text { in Costanza) } \\
\text { - Solidarity, respect, tolerance, } \\
\text { generosity, passion, receptiveness }\end{array}$ \\
\hline
\end{tabular}




\begin{tabular}{|l|l|}
\hline Understanding & $\begin{array}{l}\text { - Access to information } \\
\text { - Intuition and rationality }\end{array}$ \\
\hline Participation & $\begin{array}{l}\text { - Act meaningfully in the world } \\
\text { - Contribute to and have some } \\
\text { control over political, community, } \\
\text { and social life } \\
\text { - Being heard } \\
\text { - Meaningful employment } \\
\text { - Citizenship }\end{array}$ \\
\hline Leisure & $\begin{array}{l}\text { Recreation, relaxation, tranquillity, } \\
\text { access to nature, travel }\end{array}$ \\
\hline Spirituality & $\begin{array}{l}\text { Engaging in transcendent } \\
\text { experiences } \\
\text { - Access to nature } \\
\text { - Participation in a community of } \\
\text { faith }\end{array}$ \\
\hline Preativity/emotional \\
expression & $\begin{array}{l}\text { Play, imagination, inventiveness, } \\
\text { artistic expression }\end{array}$ \\
\hline Identity & $\begin{array}{l}\text { Status, recognition, sense } \\
\text { belonging, differentiation, sense of } \\
\text { place }\end{array}$ \\
\hline Freedom & $\begin{array}{l}\text { "Being able to live one's own life } \\
\text { and nobody else's. This means } \\
\text { having certain guarantees of non- } \\
\text { interference with certain choices } \\
\text { that are especially personal and } \\
\text { definitive of selfhood, such as } \\
\text { choices regarding marriage, } \\
\text { childbearing, sexual expression, } \\
\text { speech and employment" } \\
\text { ((Nussbaum as referenced in } \\
\text { Costanza) } \\
\text { - Mobility }\end{array}$ \\
& \\
& \\
&
\end{tabular}

\subsubsection{Subjective Well-Being (SWB)}

Between the sixties and the seventies, it was very clear that the measures of economic and social wellbeing indicating points were insufficient for capturing the true well-being of individuals; this is the reason researchers and scientists frequently investigating the variation among meanings and measurements of subjective well-being [29]. Dieneret al. (2003) [41] suggested the theory of well-being in psychology so it became major set point theory of human well-being whichever got much development during time and researches. The theory of [41] considered that everyone has his own "happiness set point", that happiness set point various for each person due to differences in each one's genes, personality and experiences of deviations as a result of living events, circumstances or situations. Dieneret al. (2003) indicates about the SWB shall be considered as a basis for the genetic form of the public, in addition to not get influenced by various aspects like environmental amenities, education, income and health. May researchers such as $[21,30]$ and a lot others concurred upon subjective well-being evaluates in addition to analyses any study about individuals lives by both of evaluations of individual's emotions and moods, also cognitive judgments of life satisfaction. The subjective wellbeing could get measured through holding interviews to groups or individuals and to ask them to start evaluating life satisfaction, well-being, utility, happiness and welfare of their own.

Subjective measurements usually focus on distinctive description of life experience that complement health, economic and social factors indicating like the degree whichever a perceived need that getting encountered in addition to the significance of this "perceived need" for person's altogether (QOL). Subjective measures normally depend upon surveys or interviews tools to collect participants' detailed evaluation for their lived experiences presented as self-reporting about satisfaction, happiness, well-being or different nearsynonym. The SWB evaluated by answers of individuals or groups for asked about happiness, life satisfaction, utility, or welfare [21]. This study is based on explaining human needs and well-being based on previous mentioned researchers and scientists. This research investigates the effect of landscape features on the quality of Egyptian life's which can be measured by Human needs and subjective well-being.

\subsection{Parks Features}

In order to describe the parks, we need to talk about parks' elements. The fundamental scope of this study is not the design of parks, the components of parks are used for estimating the main connection between parks and the (QOL). Nevertheless, to get further details regarding the components of parks you can research in $[31,32,33,34,35,36]$.

The framework of the parks features shown in figure [3] were utilized through this research. It was fostered from Moussa and Mahmoud. (2017) framework diverged the parks features into five categories as follows: 


\section{Landscape Elements}

\begin{tabular}{|c|c|c|c|c|}
\hline $\begin{array}{l}\text { 1- Trails } \\
\text { \& Paths }\end{array}$ & $\begin{array}{c}\text { 2- Designated } \\
\text { \& Specific Use } \\
\text { Areas }\end{array}$ & $\begin{array}{c}\text { 3- } \\
\text { Water } \\
\text { Areas }\end{array}$ & $\begin{array}{c}\text { 4- Other } \\
\text { Amenities \& } \\
\text { Facilities }\end{array}$ & $\begin{array}{l}\text { 5- Playground } \\
\text { Equipment \& } \\
\text { Fields \& Courts }\end{array}$ \\
\hline $\begin{array}{l}\text { - Trails } \\
\text { - Path } \\
\text { - Pavements } \\
\text { - Footpath networks }\end{array}$ & $\begin{array}{l}\text { - Open space } \\
\text { - Wooded area } \\
\text { - Picnic area } \\
\text { - Camping site } \\
\text { - Pavilion } \\
\text { - Area surrounding parks } \\
\text { - Wildlife or pet area } \\
\text { - parking lot }\end{array}$ & $\begin{array}{l}\text { - Lakes } \\
\text { - Ponds } \\
\text { - Fountains } \\
\text { - Fishing area } \\
\text { - Stream } \\
\text { - Wetland } \\
\text { Reflective Pools } \\
\text {-Waterfall }\end{array}$ & $\begin{array}{l}\text { - Benches } \\
\text { - Trash box } \\
\text { - Tables } \\
\text { - Vending mach. } \\
\text { - Telep. booths } \\
\text { - Kiosks } \\
\text { - mailboxes } \\
\text { - Sculptures } \\
\text { - Walls } \\
\text { - Fences } \\
\text { - Drink fountains } \\
\text { - Picnic shelters }\end{array}$ & $\begin{array}{ll}\text { - } & \text { Playing sets } \\
\text { - } & \text { Playing structures } \\
\text { - } & \text { Ground surfaces } \\
\text { - } & \text { Sliding down things } \\
\text { - } & \text { Standing or walking } \\
\text { - } & \text { On } \\
& \text { Climbing } \\
\text { - } & \text { Swinging/hanging } \\
& \text { from }\end{array}$ \\
\hline
\end{tabular}

\subsubsection{Trail/Path}

Several fundamental elements in landscape such as: trails, paths, pavements and footpath, these elements also let people enjoy the landscape. This landscape can be made by nature as inland waterways, mountains, forests and coastal or it can be made by man as artificial parks and farms [31, 33].

\subsubsection{Designated and Specific Use Areas}

These areas include: picnic areas, camping sites, open spaces, meadows, wooded areas, shelters (pavilion or gazebo), entertainment venues/stage, areas around parks, wildlife or pet areas and parking lots. Years ago, it was The Greeks who were the starters of making public spaces or even areas for specified usage such as the temenos and the agora [19].

\subsubsection{Water Areas}

Water represents a fundamental part in landscape. Different water features include fountains, ponds, lakes, fishing areas, streams or creeks, wetland, reflective pools and waterfalls $[32,36]$.

\subsubsection{Other Amenities and Facilities}

The execution of the site is effected positively by amenities of the site and facilities; they consist of benches, flag poles, trash receptacles, telephone booths, tables, bus shelters, vending machines, kiosks, picnic shelters, mail boxes, memorials, sculptures, bike racks, walls, fences and monuments.

\subsubsection{Playground Equipment, Fields and Courts}

This set includes: play-set, fictional play structures, grounding surfaces, anything for swinging/hanging from it, anything for climbing on/up/through, elements for standing or walking on, swings and element for sliding down, etc. It is planned to free the people away of the capture of brick walls and glass providing an area wherever kids can be playing in larger, shaded and safer spaces [34].

\section{Study Methods}

This research uses qualitative method for investigating the influence of landscape features installed in Egyptian parks and its effect on quality of human life measured in term of human needs and well-being. Qualitative surveys targeting the park visitors were undertaken in this research. Two parks 
were chosen; "Al-Azhar Park" and "Family Park" to become the study areas of the research. The surveys were conducted in order to measure the effect of landscape features toward Human needs and subjective well-being.

\subsection{Study Area}

The study chose Al-Azhar Park and Family Park randomly among the Egyptian parks because they are among the largest parks in Egypt and they were constructed lately which made they attract more visitors than other Egyptian parks.

\subsubsection{Al-Azhar Park}

Al-Azhar Park is situated in Old Cairo district. It is encircled by several historical locations as shown in figure [4], it is considered among the major parks within Cairo. Al-Azhar Park designers aimed to planning a park that re-energize that history and heritage in order to making it stimulating for economic and socially development.
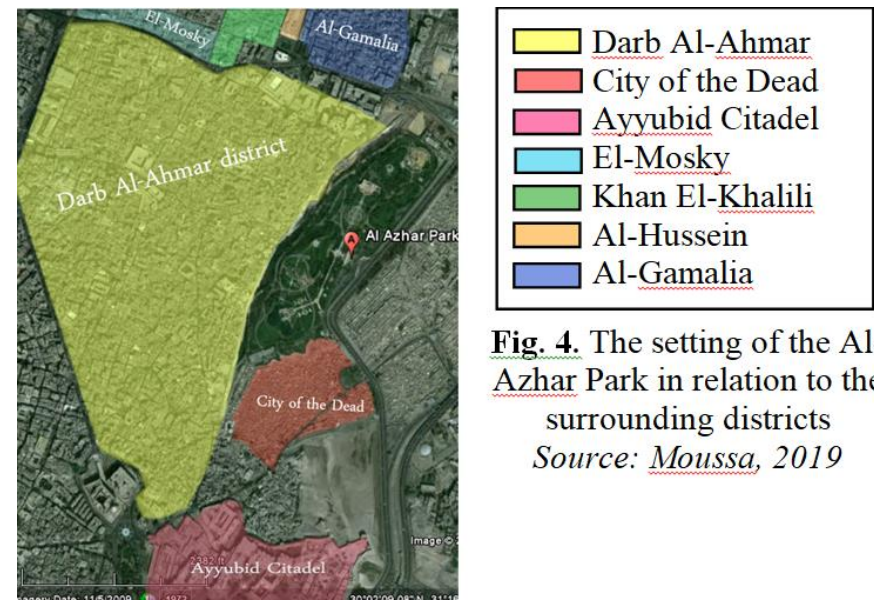

Fig. 4. The setting of the $\mathrm{Al}$ Azhar Park in relation to th surrounding districts Source: Moussa, 2019

\subsubsection{FamilyPark}

Family Park is situated in New Cairo district and it is surrounded by new urban districts as shown in figure [5], it is considered as one of the prime parks in Cairo. The Park location is considered distinctive because of its proximity to Cairo-Suez road and surrounded by new districts such as "Al-Rehab City" district and "El-tagamoa Al-awal" with different socioeconomic levels.

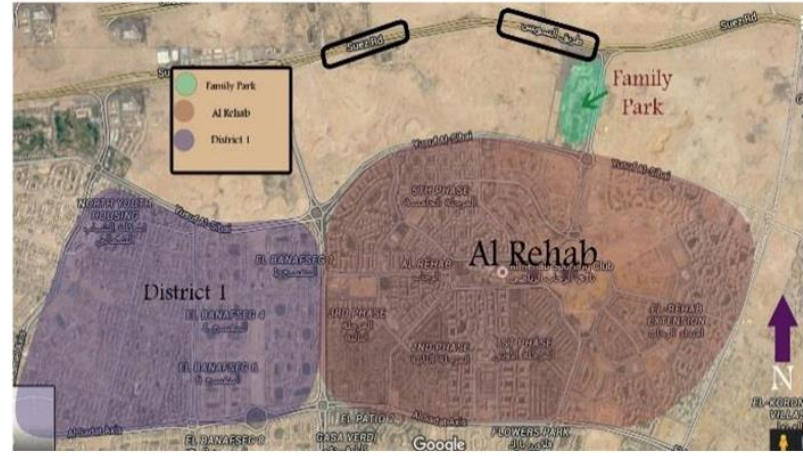

Fig. 5. The setting of Family Park in relation to the surrounding districts

\subsection{Components of Study Area}

\subsubsection{Al-Azhar Park}

The design of Al-Azhar Park is connected through a formally designed water channel spine or axis whichever held jointly through the whole length, the spine or axis represent a special theme that shows traditions from Islamic Gardens design [39, 40]. Water features are distributed and gave in to the freest shape for the lake allocated in the Sothern meadow as shown in figure [6]. Classically Islamic traditions have Gardens and pavilions, bordered with geometrically gardened orchards whichever strengthen the entry spot by the side of the lake. The cantered passageway accompanies alleyways and several formally designed gardens and anchors on each side around the hilltop restaurant and lakeside cafe, whichever acts like in park's landmarks[37, 38].A net of informally designed passageways bordering the further formally designed areas and give on along each level and corner of the site.(AEC World Expo, 2009). All these components of the park are shown in figure [6].

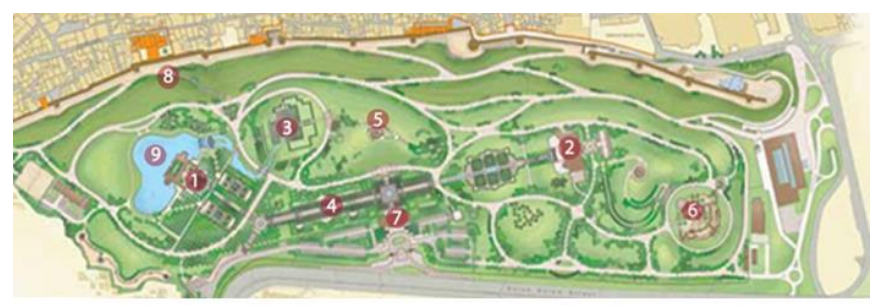

Fig. 6. Master Plan of the Al-Azhar Park and its components

Source: Moussa \& Mahmoud. 2017 


\subsubsection{Family Park}

Family Park consists of six categorizations; entertainment, cafes, services building, restaurants, educational building, gaming and greenery spaces as shown in figure [7]. The components of entertainment categorization are enjoyment village, entertainment plaza, safari plaza, safari gazelles, 3D cinema, amphitheatre, puppet theatre, Roman theatre, Roman lakeside theatre and dancing fountain. The park has good distributed number of restaurants and cafes, one of the restaurants named IBIS in addition to a couple of cafes named jungle and rendezvous, additionally five kiosks and a food court, several buildings like the main and subsidiary gates, twelve lavatories, three train stations (Rendezvous, cave and jungle), administration, emergency clinic and several gifts shops. Furthermore, the park delivers a different educational adventure for the kids throughout the exhibitions, workshops, discovery palace and the museum. The park has $20066 \mathrm{~m} 2$ of green areas.

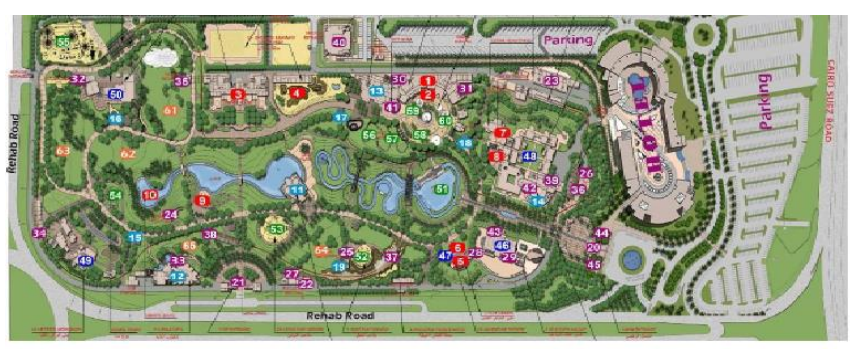

Fig. 7. Components of Family Park Source (Family Park, 2017)

\subsection{Park Visitors}

"Al-Azhar" and "Family" Parks are considered the most public attractive parks in Egypt due to its modern design and high quality. The numbers of visitor's in Al-Azhar Park and Family Park are presented below in tables 4 and 5, the data were collected from the social department of the parks. As shown in tables $4 \& 5$, the visitor's distribution shows huge differences between national vacations, weekends and working days. The numbers of visitors in Friday's are bigger than the rest of the week days, because Friday is a weekend in all Egyptian firms and businesses institutions.
Table 5. The rate of visitors of Family Park

\begin{tabular}{|l|l|}
\hline \multicolumn{2}{|c|}{ Weekly data } \\
\hline Type of day & $\begin{array}{l}\text { Number of } \\
\text { visitors }\end{array}$ \\
\hline Friday & $\begin{array}{l}7,000 \quad \text { to } \\
14,000\end{array}$ \\
\hline Saturday & 5,000 to 9,000 \\
\hline Sunday & 2,800 to 7,000 \\
\hline Monday & 2,800 to 7,000 \\
\hline Tuesday & 2,800 to 7,000 \\
\hline Wednesday & 2,800 to 7,000 \\
\hline Thursday & $\begin{array}{l}5,600 \text { to } 10, \\
000\end{array}$ \\
\hline
\end{tabular}

\begin{tabular}{|l|l|}
\hline \multicolumn{2}{|c|}{ National vacations } \\
\hline Type of day & $\begin{array}{l}\text { Number } \\
\text { of } \\
\text { visitors }\end{array}$ \\
\hline Eastern vacation & 15,475 \\
\hline Adha 1st day & 19,625 \\
\hline Adha 2nd day & 22,720 \\
\hline Adha 3rd day & 21,109 \\
\hline Adha 4th day & 10,945 \\
\hline Sham el Nesem & 40,420 \\
\hline 6 of october & 18,910 \\
\hline
\end{tabular}

\subsection{Data Collection Questionnaires}

This research conducted the qualitative survey in the form of detailed questionnaires. Two questionnaires took place in this research; the first questionnaire targets the visitors of Al-Azhar Park. While the second questionnaire, target the visitors of Family Park. Each questionnaire was split into two parts. The first one consists of seven questions corresponding to visitor characteristics such as: Name, age, gender, career, educational level, the number of visiting the park which is the study area of the research. The second part of the questionnaire consists of 65 questions, each question measures the effect of the chosen park elements (representing the landscape features), and its effect on each (QOL) aspects (which represent the aspects of Human needs and SWB). The Park visitors were asked to indicate how closely the feature installed in AlAzhar Park and Family Park affect the aspects of human needs and subjective well-Being. The visitors were asked to rate each feature from 'totally disagree' ( 1 point) to 'totally agree' ( 7 points) in sequence of measuring the effects of landscape features on the 'quality of Egyptian life's' with regards of measuring the 'human needs' and 'subjective well-being'.

\subsection{Characteristics of Participants}

The total number of participants participated in this research are 735 persons. The survey took place between December 2019 and January 2020. The participants were selected randomly amongst AlAzhar Park and Family Park visitors. The research sample started with 890 participants, but only 735 participants were considered as those are the sample that answered all the questions. It was noticed that an average of 155 participants answered less than 
$70 \%$ of the questionnaire because they found the questionnaire too long. 410 participants out of 735 participants participated in the research from AlAzhar Park while 325 are the number of participants participated from Family Park. The age of the participants ranged between 20 to 49 years and they were selected randomly amongst the visitors. $65 \%$ of them were regular visitors that visited the park more than once, while the rest visited the park for the first time on the day of the questionnaire.

\subsection{Procedures}

This research depended on the qualitative questionnaire for data collection; the survey was conducted between December 2018 and January 2019. Two questionnaires took place in this research; the first questionnaire targeted the visitors of Al-Azhar Park meanwhile, the other questionnaire has been done in Family Park. 735 people chose to join the survey of this research. 410 participants participated from Al-Azhar Park while

Table 4. The rate of visitors of Al-Azhar Park

\begin{tabular}{|c|c|c|c|}
\hline \multicolumn{2}{|c|}{ Weekly data } & \multicolumn{2}{|c|}{ National vacations } \\
\hline $\begin{array}{l}\text { Type of } \\
\text { day }\end{array}$ & $\begin{array}{l}\text { Number of } \\
\text { visitors }\end{array}$ & Type of day & $\begin{array}{l}\text { Numbe } \\
\mathbf{r} \text { of } \\
\text { visitors }\end{array}$ \\
\hline Friday & 10,000 to 15,000 & Eastern vacation & 20,125 \\
\hline Saturday & 9,000 to 11,000 & Adha 1st day & 26,946 \\
\hline Sunday & 4,000 to 8,000 & Adha 2nd day & 35,445 \\
\hline Monday & 4,000 to 8,000 & Adha 3rd day & 32,177 \\
\hline Tuesday & 4,000 to 8,000 & Adha 4th day & 13,1414 \\
\hline Wednesday & 4,000 to 8,000 & Sham el Nesem & 47,9400 \\
\hline Thursday & 9,000 to 11,000 & 6 of october & 30,157 \\
\hline
\end{tabular}

325 participants participated from Family Park.

People were oncoming in each park then they were told about the objectives meant by the survey and also the proper procedures to answer all questions. With a view to reflect peoples' reflection of their on spot experience, those wanting to join by choice were given the questions and got asked to answer the questions within still staying in the area. The questions were narrated to the participants before they started answering them to make sure that they acknowledge all of the questions. The questionnaires were handed out all week, both on weekends and working days, at various times of each day and in several areas of the park. The software used for statics SPSS 17.0 was utilized to perform statistical analysis in order to analyse the data collected and each data subdivided to pull out the main parameters of the correspondent scale by employing the Mean value and the standard deviation. Subsequently, all of the data collected were statistically analyzed by SPSS program in preparation for measuring the effect of landscape features for the 'quality of Egyptian life' in terms of 'human needs' and 'subjective well-being'.

\section{Results}

The questionnaire conducted in this research was self-reported, whichever assess background information, behaviours in addition to psychological trails with reference to the visitor's life gratification to Egyptian parks. The data collected from the 735 participants were used analysed. The main set of data got split to 65 data subsets, corresponding to 65 variables that were observed the connection between each landscape feature implemented in the park with the aspects of human need subjective well-beings. Statistical software SPSS 17 was used to analyse the data and tested the Standard Deviation and the Mean value to the collected data. The results of this study and explained and summarized by the following tables and charts.

\subsection{Descriptive analysis of Al-Azhar park Questionnaire}

Table [6] summarizes the response to the main questionnaire. The number of participants that answered each question $(\mathrm{N})$ could be calculated as $\mathrm{N}=5^{*} 410$, where 5 represent the parks features and 410 represent number of participant. Mean value is the mean value of one aspect with the five elements of park which indicate five places inside the park. Std. Deviation is the Standard deviation of response of the participants on one aspect in the five places inside the park. The main findings of table [6] are: The participants find that all the (QOL) aspects are significant in the five elements or places of the park depending on Mean value that were concluded from the participant responses, mean value is above 4 which represent the moderate response in questionnaire. It revealed that Affection and Happiness are the most effected aspects in the park, while Participation, Understanding and Welfare are 
the most unaffected aspects in Al-Azhar Park as shown below in table [6].

\subsection{Descriptive analysis of Family Park Questionnaire}

Table [7] shows a summary of the main properties of the response to the main questionnaire. The number of participants that answered each question (N) could be calculated as $\mathrm{N}=5 * 325$, where 5 represent the parks features and 325 represent number of participant. Mean value is the mean value of one aspect with the five elements of park which indicate five places inside the park. Std. Deviation is the Standard deviation of response of the participants on one aspect in the five places inside the park. The main findings of table [7] are:

The participants find that all the (QOL) aspects are significant in the five elements or places of the park depending on Mean value that were concluded from the participant responses, mean value is above 4 which represent the moderate response in questionnaire.

Table 7. The Mean value and standard deviation of Family Park participants

\begin{tabular}{lccc}
\multicolumn{4}{c}{ Park participants } \\
\hline Analysis & N & Mean & Std. Deviation \\
\hline Subsistence & 1625 & 4.41 & 1.767 \\
Security & 1624 & 4.20 & 1.715 \\
Affection & 1623 & 4.63 & 1.706 \\
Understanding & 1625 & 4.18 & 1.706 \\
Participation & 1624 & 4.18 & 1.680 \\
Leisure & 1625 & 4.37 & 1.627 \\
Spirituality & 1625 & 4.56 & 1.611 \\
Creativity & 1623 & 4.27 & 1.614 \\
Identity & 1620 & 4.16 & 1.676 \\
Freedom & 1625 & 4.25 & 1.681 \\
Happiness & 1625 & 4.84 & 1.785 \\
Utility & 1622 & 4.09 & 1.841 \\
Welfare & 1625 & 4.12 & 1.752 \\
\hline 3.3 & &
\end{tabular}

\subsection{Relation between Al-Azhar park Elements and (QOL) Aspects}

The subsequent tables illustrate the connection between all of the elements of the park on the different (QOL) aspects. In preparation for acknowledging the implication of elements on (QOL) characteristics, it was decided to select the characteristic that the participants announced over 5 to be the highest gratification characteristics that please the park visitors. The total number of response is 7 and 4 is the moderate effect so we

Table 6. The Mean value and standard deviation of Al-Azhar Park participants

\begin{tabular}{lrrr}
\hline Analysis & N & Mean & Std. Deviation \\
\hline Subsistence & 2050 & 4.42 & 1.812 \\
Security & 2050 & 4.86 & 1.622 \\
Affection & 2046 & 4.99 & 1.644 \\
Understanding & 2049 & 4.15 & 1.798 \\
Participation & 2050 & 4.03 & 2.322 \\
Leisure & 2049 & 4.84 & 1.802 \\
Spirituality & 2050 & 4.92 & 1.799 \\
Creativity & 2050 & 4.72 & 1.739 \\
Identity & 2050 & 4.46 & 1.753 \\
Freedom & 2050 & 4.68 & 1.729 \\
Happiness & 2050 & 5.05 & 1.689 \\
Utility & 2048 & 4.30 & 1.789 \\
Welfare & 2048 & 4.16 & 1.855 \\
\hline
\end{tabular}

chose 5 which is more than the moderate to make clear that this characteristic is pleasing the visitors of the park in those specific areas. From 4 to 4.9 was decided to be the moderate value, and less them 4 if the lowest gratification characteristics that please the visitors. In the subsequent tables, significant (QOL) characteristics are dark shaded while non-significant aspects are faded.

Table 8. Relation between (QOL) aspects and Al-Azhar park landscape features

\begin{tabular}{|c|c|c|c|c|}
\hline \multicolumn{5}{|c|}{ Elements of Parks } \\
\hline Trails/Path & $\begin{array}{c}\text { Designated \& } \\
\text { Specific use } \\
\text { areas }\end{array}$ & Water Areas & $\begin{array}{c}\text { Other } \\
\text { Amenities \& } \\
\text { facilities }\end{array}$ & $\begin{array}{c}\text { Playground } \\
\text { equipment \& } \\
\text { fields \& } \\
\text { courts }\end{array}$ \\
\hline Security & Security & Security & Subsistence & Security \\
\hline Affection & Affection & Affection & Security & Affection \\
\hline Leisure & Leisure & Understanding & Affection & Freedom \\
\hline Spirituality & Spirituality & Leisure & Leisure & Happiness \\
\hline Creativity & Creativity & Spirituality & Happiness & \\
\hline Identity & Identity & Creativity & & \\
\hline Freedom & Freedom & Identity & & \\
\hline Happiness & Happiness & Freedom & & \\
\hline & & Happiness & & \\
\hline & & Utility & & \\
\hline
\end{tabular}


WSEAS TRANSACTIONS on ENVIRONMENT and DEVELOPMENT DOI: 10.37394/232015.2022.18.11
Marianne Nabil Guirguis, Rania Rushdy Moussa, Khaled M. Dewidar, Naglaa Mohamed Yossif
Very strong satisfaction: Security, Affection and Happiness

Strong satisfaction: Leisure and Freedom

Moderate satisfaction: Spirituality, Creativity and Identity

Weak satisfaction: Subsistence, Understanding and Utility

Table 9.Relation between (QOL) aspects and Family park landscape features

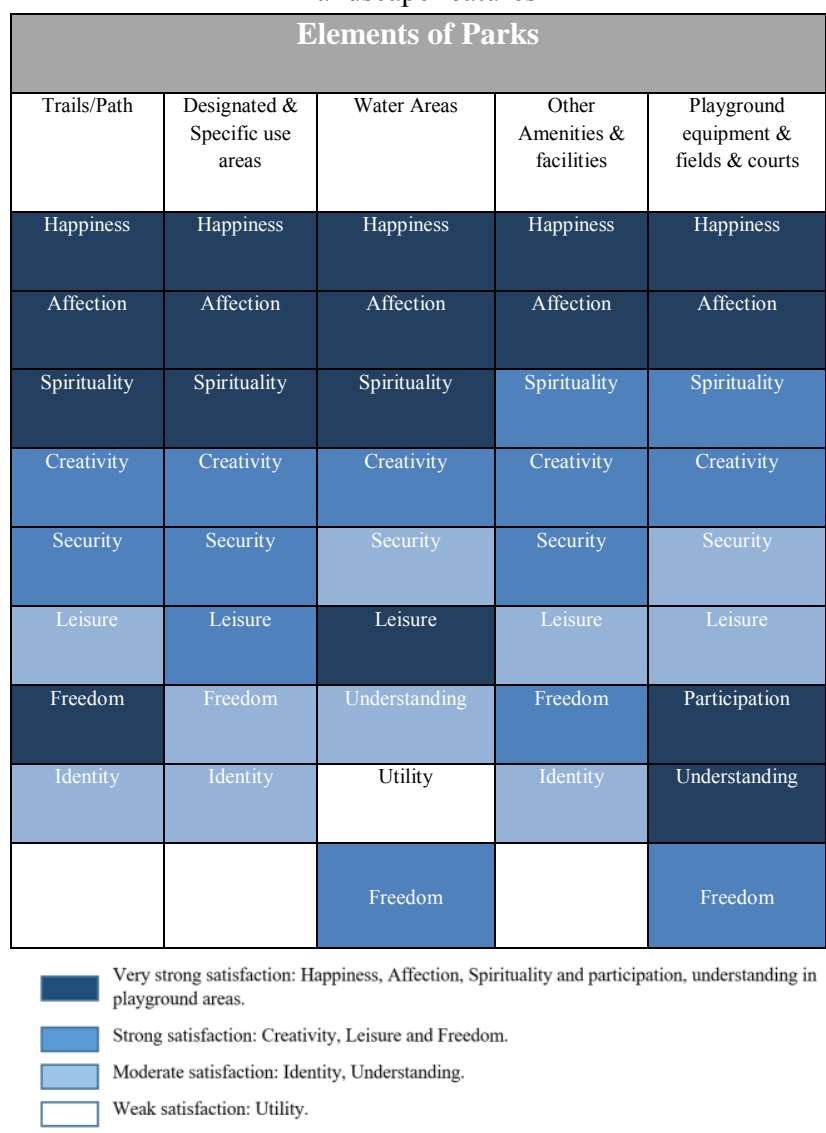

The findings of this research gave out that the landscape features installed in the parks have major participation for human needs and subjective wellbeing (SWB). These results were introduced on various figures as shown in figures $(8,9,10,11,12$, $13,14,15,16$ and 17). The figures demonstrate the effect of Al-Azhar Park and Family Park elements which illustrate several areas in each park on each (QOL)aspect. The graphs represent the mean value (5 or more) in order to be the significant aspect. Since the highest value in the answers is 7 and 1 is the lowest value while 4 is the moderate one, it was decided to take the value of 5 or more as a significant value and a range between 4.5 to 5 to be the moderate significant value in order to make sure that the aspect is really valid.

The study investigated to eventually conclude the similarities and the differences between the effect of landscape features inside Al-Azhar Park and Family Park on (QOL) aspects.

The results of this research revealed that the Egyptians feel a high level of happens and Affection in both parks while they were not satisfied with Egyptian parks the utilities and welfare as shown in figures 18 and 19.

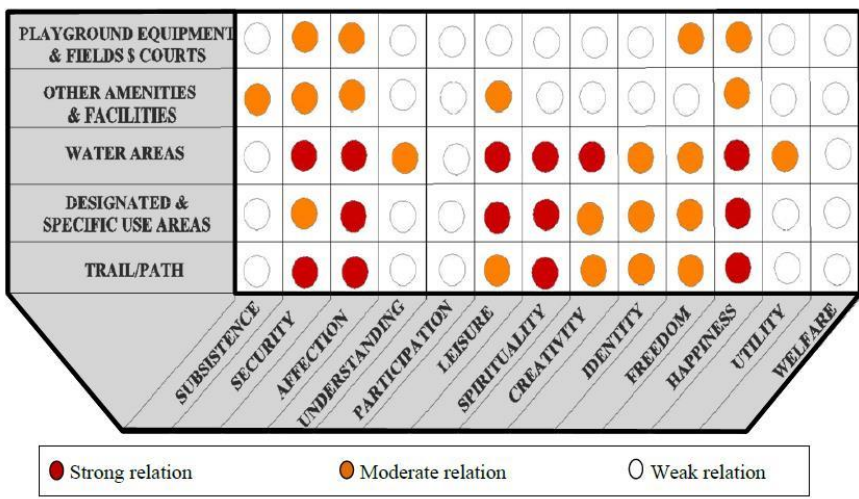

Fig. 18. Effect of Elements of Al-Azhar Parks on QOL aspects

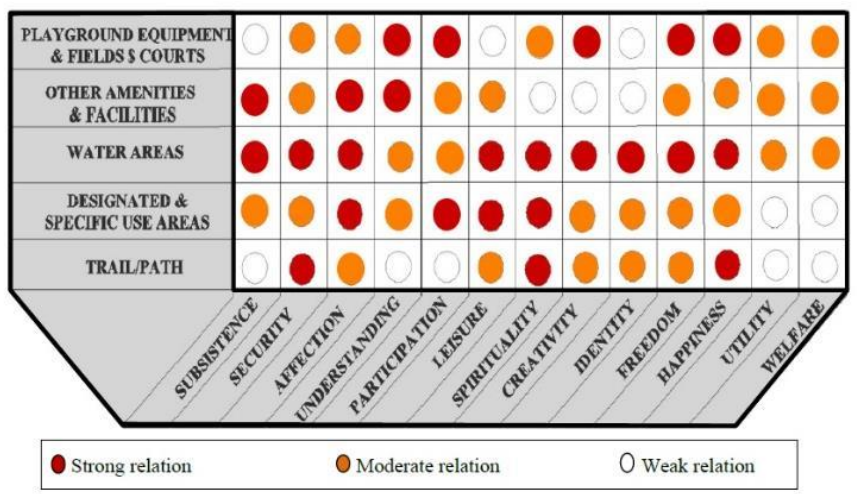

Fig. 19. Effect of Elements of Family Parks on QOL aspects

\section{Conclusion}

After analysing the results, it was conducted that a lot of landscape features put up to human needs and SWB. The study additionally showed that the features of parks have a major consequence for fulfilling the (QOL) aspects mainly specific needs like 'Happiness' and 'Affection'.

The case study survey demonstrates that people like to visit the Egyptian Parks and this is the reason of higher level of happiness in all the parks features whichever exemplify several places in Al-Azhar Park and Family Park. Nevertheless, visitors do not have the feeling of a good relation to welfare and they only find few places or not enough activities to join in or to allow them to get to know new people except for the 'Playgrounds Equipment \& Fields \& Courts' whichever resemble the kids' areas in the 
park. A significant number of people identify the areas with water such as fountains and the lake, places that come up with opportunities to learn new things. This study substantially concluded that respondent's perception, normally, of (QOL) of districts belonging to them were strengthened as a result of Al-Azhar Park and Family Park development. These projects present a good chance of having pleasing jobs, urban services and sufficient infrastructure; in addition to increasing commercial values whichever add to the income. (interview with Al-Azhar park and Family Park managers). Therefore, the municipal authorities and those responsible for planning the city, must put great significance of this type of projects in alike areas.

These investigation findings are compatible to the research hypothesis. Needless to say, several aspects of the QOL are very hard to be influenced, but this study specifies precedents to assign resources to enhance the QOL at homogeneous districts of the old core of Cairo and new districts like New Cairo.

The fundamental finding of this study is the major influence of parks on QOL and human satisfaction. Furthermore, this study investigated the positively effects of parks and nature-made environment on meeting the human needs and well-being. The presented study measured the effect of different park elements on each aspect of human need and well-being. Parks and trees in urban levels have evinced beneficial environmentally, socially and economically for architects, landscape architects and urban planners. Urban parks are once seen as an aesthetic element of the city but not anymore, now it has become a fundamental part of the urban ecosystem. Careful utilization of those the five elements of parks with along aware studying the economic and environmental context would surely assist to establish sustainable (QOL) among any urban area. Parks, recreation and public health executives need to enhance their research and to not limit their data to show a growth in park visits ahead. It is needed to be proved that park visits got a lot of measurable benefits for human health, social life and economic income. Parks need to have some measurable benefit for human (QOL).

\section{References:}

[1] Forward, S. (2003). State of the Art Report on Life Quality Assessment in the Field of Transport and Mobility. Linkoepin- Sweden: Swedish National Road and Transport Research Institute.

[2] Galloway, S. (2005). Quality of Life and Wellbeing: Measuring the Benefits of Culture and Sport: Literature Review and Think Piece. Eidenburgh: Scottish Executive Social Research

[3] Caiman, K.C. (1984). Quality of life in cancer patients - a hypothesis. J. Med. Ethics 10, 1551.

[4] Wish, N.B. (1986). Are we really measuring the quality of life? Well-being has subjective dimensions, as well as objective ones. American Journal of Economics and Sociology 45 (1), $93 \pm 99$.

[5] Liu, B.C. (1976). Quality of Life Indicators in US Metropolitan Areas: A Statistical Analysis. Praeger, New York.

[6] Boyer, R. and Savageau, D. (1981). Places Rated Almanac. Rand McNelly, Chicago.

[7] Blomquist, G.C., Berger, M.C. and Hoehn, J.P. (1988). New estimates of quality of life in urban areas. American Economic Review 78 (1), 89107.

[8] Stover, M.E. and Leven, C.L. (1992). Methodological issues in the determination of the quality of life in urban areas. Urban Studies 29 (5), $737 \pm 754$.

[9] Sufian, A.J.M. (1993). A multivariate analysis of the determinants of urban quality of life in the worldÕs largest metropolitan areas. Urban Studies 30 (8), $1319 \pm 1329$.

[10] Ulengin, B., Ulengin, F. and Guvenc, U. (2001). A multidimensional approach to urban quality of life: The case of Istanbul, 'European Journal of Operational Research', Volume 130, pp 361374.

[11] Dyck, B. (2003). Benefits of Planted Forests: Social, Ecological and Economic. Wellington, New Zealand: Science \& Technology Broker, PO Box 11236 Palm Beach.

[12] Sherer, P.M. (2003). Report: The benefits of parks: why America needs more city parks and open space. San Francisco: Parks for people. 
[13] Kimhi, I. (2005). Urban Environ mental Quality. The Jerusalem Institute for Israel Studies, The Center for Environmental Policy.

[14] Tyrväinen, L., Pauleit, P., Seeland, K. and de Vries, S. (2005). Urban Forests and Trees: Chapter 4 Benefits and Uses of Urban Forests and Trees. Netherlands: Springer.

[15] Prato, T. and Fagre, D. (2006). National Parks \& Protected Areas: Approaches for Balancing Social, Economic, and Ecological Values. State Ave: 2121 State Ave., Ames, IA 50014. 2005. 446 p. \$124.99, hardcover. ISBN 0-8138-12488.

[16] Mahmoud, A. and Rushdy, R. (2009). The Role of Park Planning in Enhancing the Quality of Urban Environments. England, 2nd international Conference on whole life urban sustainability and its assessment-Loughborough University.

[17] Priego, C. and Canales, G., (2008). Environmental, social and economic benefits of tree plantations for urban societies. Cordova, Spain. Report. Andalusia: Institute for advanced social studies of Andalusia, IESA-CSIC, Campo Santo de los Martires 7, 14004.

[18] Farquhar, M. (1995). Elderly people's definitions of quality of life. Britain, Elsevier Science Ltd Soc. Sci. Med. Vol. 41, No. 10, pp. 1439-1446.

[19] Denham, M.J. (1983). Assessment of quality of life. In Care of the Long-stay Patient (Edited by Denham M. J.). Croom Helm, Beckenham.

[20] Townsend, P. and Gordon, D. (1992). Unfinished statistical business on low incomes? A review of new proposals by the Department of Social Security for the production of public information on poverty. University of Bristol, Report 3, Statistical Monitoring Unit Series.

[21] Costanza, R., Fisher, B., Ali, S., Beer, C., Bond, L., Boumans, R., Danigelis, N.L., Dickinson, J., Elliott, C., Farley, J., Gayer, D.E., Glenn, L.M., Hudspeth, T., Mahoney, D., McCahill, L., McIntosh, B., Reed, B., Rizvi, S.A.T., Rizzo, D.M., Simpatico, T. and Snapp, R. (2007). Quality of life: An approach integrating opportunities, human needs, and subjective well-being. Elsevier B.V., Ecological Economics 61 (2007) 267-276.
[22] Pfeifer, A.A. (1998). Abraham Maslow's hierarchy of needs: A Christian perspective. Austria, The 22' Integration Faith and Learning Seminar SchlossBogenhofen.

[23] KÖK, H. (2007). Reducing Violence: Applying the Human Needs Theory to the Conflict in Chechnya. UluslararasHukukvePolitika, Cilt3, No: 11 ss.89-108, 2007.

[24] Max-Neef M. (1991). On Human Needs and Human Scale Development. Available on http://www.rainforestinfo.org.au/background/m axneef.htm. Human Scale Development, published in 1987 in Spanish and Human Scale Development, published in 1991, New York: Apex Press.

[25] Burton, J. (1990). Conflict Resolution and Prevention, New York: St. Martins Press.

[26] Gough, I. and Doyal, L. (1991). A Theory of Human Need. The Macmillan Press, Basingstoke.

[27] Rosenberg, M. (2003). Non Violent Communication. A Language of Life. California, Puddle Dancer Press.

[28] Max-Neef, M. (1992). Development and human needs. In: Ekins, P., Max-Neef, M. (Eds.), Real life Economics: Understanding Wealth Creation. Routledge, London, pp. 97-213.

[29] Vemuri, A.W. and Costanza, R. (2006). The role of human, social, built, and natural capital in explaining life satisfaction at the country level: Toward a National Well-Being Index (NWI). Elsevier B.V., Ecological Economics, 58 (2006) 119- 133.

[30] Diener, E. and Suh, E.M., (1999). National differences in subjective wellbeing. In: Kahneman, D., Diener, E. and Schwarz, N. (Eds.), Well-Being: The Foundations of Hedonic Psychology. Russell Sage Foundation, New York, pp. 444-450.

[31] Ferris, C.-I. (2009). Recreation and the Landscape: Providing Trails - A Consideration of the Challenges Presented in Delivering Trail Networks for Recreation. Irish National Landscape Conference 2009.

[32] Hong, S.-K., Nakagoshi, N., Fu, B.J., and Morimoto, Y. (2008). Landscape Ecological Applications in Man-Influenced Areas: Linking Man and Nature Systems, chapter 30: Linking 
Man and Nature Systems, 505-523. Springer Science+ Business Media B.V. 2008.

[33] Johnson, L.M. (2010).Trail of Story, Traveller's Path. Canada, AU Press, Athabasca University.

[34] Prow, T. (1999). The Power of Trees. The Illinois Steward, Volume 7 Issue 4.

[35] Saelens, B.E., Frank, L.D., Auffrey, C., Whitaker, R.C., Burdette, H.L. and Colabianchi, N. (2006). Measuring Physical Environments of Parks and Playgrounds: EAPRS Instrument Development and Inter-Rater Reliability. Journal of Physical Activity and Health 2006, 3, Suppl 1, S190-S207.

[36] Sienkowska, H. (1990). Water in the landscape of a town using the example of Gdansk and Gdansk conurbation. Hydrological Processes and Water Management in Urban Areas, IAHS Publ. no. 198, 1990.

[37] Moussa, R.R. and Dewidar, K.M. (2020). Energy-scape web-based application is an effective tool to overcome the basic knowledge of architects toward renewable energy properties. International Journal of Emerging Technologies in Learning (iJET), 15(10); 42-54. Retrieved from: https://doi.org/10.3991/ijet.v15i10.13669

[38] Moussa, R.R., Mahmoud, A.H., and Hatem, T.M. (2020). A digital tool for integrating renewable energy devices within landscape elements: Energy-scape online application. Journal of Cleaner Production, 254; 1-13. Retrieved from: https://doi.org/10.1016/j.jclepro.2019.119932

[39] Moussa, R.R. (2018). The role of energy-scape elements in creating sustainable economic project in Egyptian parks. Ain Shams Engineering Journal, 9(4); 3045-3053.Retrieved from: https://doi.org/10.1016/j.asej.2018.09.001

[40] Moussa, R.R., and Mahmoud, A.H., (2017). Energy-scape Elements: An Approach on Integrating Landscape Elements with Renewable Energy Devices. Journal of Cleaner Production, 153; 114-130. Retrieved from: https://www.sciencedirect.com/science/article/pi i/S0959652617305127

[41] Diener, E., Oishi, S., Lucas, R.E. (2003) Personality, Culture, and Subjective WellBeing: Emotional and Cognitive Evaluations.
Annual Review of Psychology, 54:403-425 of

\section{Contribution of individual authors to the creation of a scientific article (ghostwriting policy)}

Rania Moussa, \& Marianne Nabil, carried out the analysis and comparison.

Marainne Nabil, Khaled Dewidar and Naglaa Youssef organized and executed the manuscript.

\section{Creative Commons Attribution License 4.0} (Attribution 4.0 International, CC BY 4.0)

This article is published under the terms of the Creative Commons Attribution License 4.0

https://creativecommons.org/licenses/by/4.0/deed.en US 